\title{
Molybdenum application forms associated to topdressing nitrogen fertilization in the production of maize crops
}

\author{
Renê José dos Santos ${ }^{1}$, José Henrique Bizzarri Bazzo ${ }^{2, *}$, André Prechlak Barbosa² and Claudemir Zucareli²
}

${ }^{1}$ Ubyfol, Avenida Alexandre Barbosa, n 360, CEP: 38060-200, Uberaba, Minas Gerais, Brazil. ${ }^{2}$ Universidade Estadual de Londrina, Rodovia Celso Garcia Cid - PR 445 Km 380, s/n - Campus Universitário, CEP: 86057-970, Londrina, Paraná, Brazil. *Corresponding author, E-mail: agro.bazzo@gmail.com

\begin{abstract}
Nitrogen fertilization associated to the application of molybdenum (Mo) can increase grain yield in maize crops. Therefore, the objective of this study was to evaluate the effect of molybdenum application forms associated to topdressing nitrogen fertilization on production components and maize crops grain yield. The experiment was conducted with the cultivar Pioneer ${ }^{\circledR} 30 \mathrm{~F} 53 \mathrm{H}$, under a randomized blocks experimental design, with subdivided parcels and four replications. Four forms of Mo applications were evaluated in each parcel: control (without Mo); seeds treatment (40 $\mathrm{g} \mathrm{ha}^{-1} \mathrm{Mo}$ ); foliar treatment (40 $\left.\mathrm{g} \mathrm{ha}^{-1} \mathrm{Mo}\right)$; seeds treatment $\left(20 \mathrm{~g} \mathrm{ha}^{-1} \mathrm{Mo}\right)$ plus foliar treatment $\left(20 \mathrm{~g} \mathrm{ha}^{-1} \mathrm{Mo}\right)$, using potassium molybdate as Mo source. The sub-parcels received four dosages of nitrogen $(\mathrm{N})$, in topdressing $\left(0,80,160\right.$ and $\left.240 \mathrm{~kg} \mathrm{ha}^{-1} \mathrm{~N}\right)$, in the form of urea. The experiment evaluated plant height, ear insertion height, stem diameter, number of grains per ear, 100 grains mass and grain yield in maize crops. The increase in $\mathrm{N}$ dosages in topdressing increases plant height, ear insertion height, stem diameter, number of grains per ear, 100 grains mass and maize crop grains yield. The application of molybdenum improves $\mathrm{N}$ absorption by maize crops. When applied via seeds treatment, Mo brings better results to foliar application in partial or total dosages.
\end{abstract}

Key words: Zea mays L., nitrogen, potassium molybdate, fertilization.

\section{INTRODUCTION}

Maize (Zea mays L.) represents one of the main and more traditional cereals grown around the world due to the important role it plays in the different links of the agribusiness chain. In function of the amount and nature of the reserves accumulated in grains, the culture stands out as a source of products for human and animal nutrition. In addition, it has been widely used as raw material by industries (Ferreira et al., 2011).

According to Cantarella and Duarte (2004), gains in maize crop grains are brought by the increase in nitrogen fertilizers use, among other factors, which, according to Silva et al. (2006b), is due to the fact that $\mathrm{N}$ is considered the most quantitatively important element for the crop. Ohland et al. (2005) state that the species is highly responsive to $\mathrm{N}$ fertilization, showing positive responses for the grain yield and productivity components. Raij (2011) emphasizes that, for maize, production can be reduced to half without top dressing nitrogen fertilization.

Brazilian soils do not supply plants demand for N (Ernani 2003), the element responsible for a series of metabolic functions that determine the adequate growth and development of plants (Yano et al., 2005), thus making complementation with nitrogen fertilizers essential. In this context, the research recommends the subdivision of $\mathrm{N}$ fertilization, making part of the nutrient available during seeding and the rest in topdressing, taking into consideration the content of the organic matter, area history, and expected yield. Fancelli (2010) recommends topdressing to be realized when the maize plant shows four leaves completely unfolded, and the maximum limit for application is when the plant has eight leaves fullyexpanded.

Among macronutrients, $\mathrm{N}$ is the element with better responses to photo-assimilated production. Assimilation takes place under nitric form and is reduced to ammonia in the plant through the action of nitrate reductase enzyme. This enzyme activity is highly dependent on Mo. (Bull 1993). Thus, Mo plays a fundamental role in the incorporation of $\mathrm{N}$ by plants, acting as an enzymatic co-factor that contributed positively to the nitrate reductase activity in the assimilation process of $\mathrm{N}$ (Martens and Westermann 1991).

Ferreira et al. (2001) observed that, in maize crops, molybdenum fertilization increased maize grains protein content by 3\%. According to Marschner (1995), this positive influence of Mo on protein content may be due to its action on the metabolism of $\mathrm{N}$, resulting in greater incorporation of this element in proteins.

Therefore, Mo alters maze growth and development directly and, consequently, grain yield and protein production through $\mathrm{N}$ metabolism.

Based on this context, the objective of this work was to evaluate the effects of molybdenum application forms associated with topdressing nitrogen fertilization on production components and maze crops grain yield.

\section{MATERIALS AND METHODS}

The experiment was conducted in the county of Londrina-PR, in Red Latosol eutroferric (EMBRAPA 2006) located at $23^{\circ} 23^{\prime} \mathrm{S}$ and $51^{\circ} 11^{\prime} \mathrm{O}$, with $566 \mathrm{~m}$ of altitude. Climate in the region is of the Cfa type, described as subtropical humid, with hot summers, according to the Köpen classification. The Paraná Agronomic Institute 
Weather Station provided the rainfall and maximum and minimum temperature data for the experiment (Figure 1).

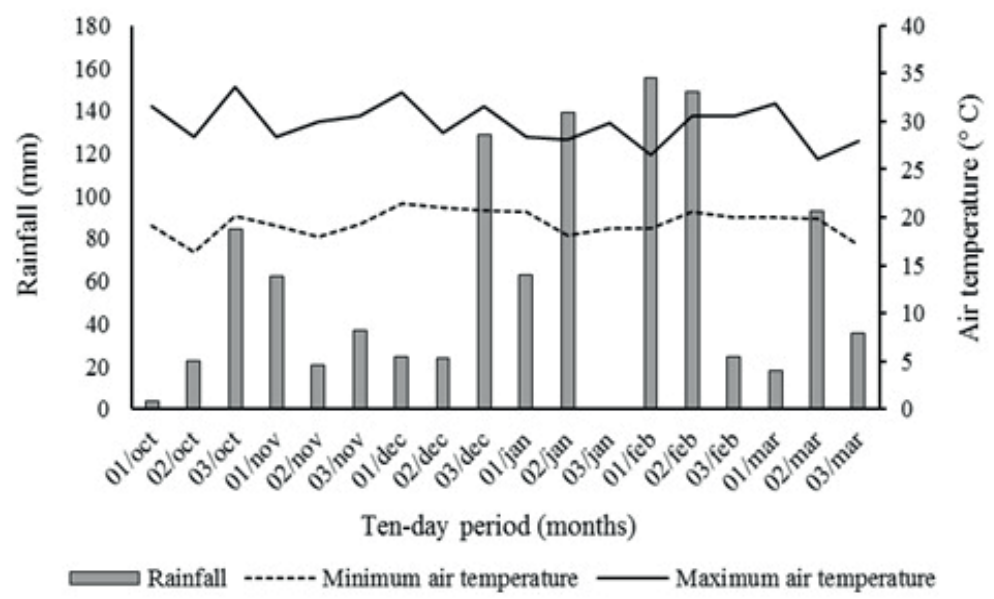

Figure 1. Rainfall and minimum and maximum temperatures registered during the experiment at Universidade Estadual de Londrina School Farm. Londrina, PR, Brazil. 2013.

The following chemical characteristics of the soil were determined, prior to the experiment's installation, at $0-10$ cm and 10-20 cm of depth: 0 to $10 \mathrm{~cm}-\mathrm{pH}\left(\mathrm{CaCl}_{2}\right) 5.49 ; 3.94 \mathrm{cmol}_{\mathrm{c}} \mathrm{dm}^{-3}$ of $\mathrm{H}+\mathrm{Al}^{3+} ; 5.4 \mathrm{cmolc} \mathrm{dm}^{-3} \mathrm{of} \mathrm{Ca}^{2+}$; $1.53 \mathrm{cmolc} \mathrm{dm}^{-3}{\mathrm{de} \mathrm{Mg}^{2+}}_{0} ; 0.87 \mathrm{cmolc} \mathrm{dm}^{-3}$ of $\mathrm{K}^{+} ; 11.41 \mathrm{mg} \mathrm{dm}^{-3}$ of $\mathrm{P} ; 29.64 \mathrm{~g} \mathrm{dm}^{-3}$ of organic matter and $66.42 \%$ of base saturation; and 10 to $20 \mathrm{~cm}-\mathrm{pH}\left(\mathrm{CaCl}_{2}\right) 5.49 ; 3.66 \mathrm{cmolc} \mathrm{dm}^{-3}$ of $\mathrm{H}+\mathrm{Al}^{3+} ; 4.91 \mathrm{cmolc} \mathrm{dm}^{-3} \mathrm{of} \mathrm{Ca}^{2+} ; 1.37$ cmolc dm ${ }^{-3}$ of $\mathrm{Mg}^{2+} ; 0.57 \mathrm{cmolc} \mathrm{dm}^{-3}$ of $\mathrm{K}^{+} ; 8.08 \mathrm{mg} \mathrm{dm}^{-3}$ of $\mathrm{P} ; 27.00 \mathrm{~g} \mathrm{dm}^{-3}$ of organic matter and $65.21 \%$ of base saturation.

The experiment was conducted under direct seeding in an area previously occupied by a wheat crop. The calculation of the basic mineral fertilization in the seeding sulcus was based on the soil chemical characteristic, constant for all treatments, which was of $28 \mathrm{~kg} \mathrm{ha}^{-1}$ of N, $70 \mathrm{~kg} \mathrm{ha}^{-1}$ of $\mathrm{P}_{2} \mathrm{O} 5$ and $35 \mathrm{~kg} \mathrm{ha}^{-1}$ of $\mathrm{K}_{2} \mathrm{O}$, using the 08-20-10 formula.

The maze cultivar used was the Pioneer ${ }^{\circledR} 30 \mathrm{~F} 53 \mathrm{H}$, which presents high production potential, precocity and high response to crop treatments and management. The experimental design was that of randomized blocks with subdivided parcels and four replications. Parcels corresponded to four Mo application forms, using potassium molybdate as source of Mo: P1 = Control (without Mo); P2 = Seeds treatment (40 $\mathrm{g} \mathrm{ha}^{-1}$ of Mo); P3 = Foliar treatment $\left(40 \mathrm{~g} \mathrm{ha}^{-1}\right.$ of Mo); and P4 = Seeds treatment $\left(20 \mathrm{~g} \mathrm{ha}^{-1}\right.$ of Mo $)+$ Foliar treatment $\left(20 \mathrm{~g} \mathrm{ha}^{-1}\right.$ of Mo $)$ and the sub-parcels with four dosages of $\mathrm{N}$ in topdressing $\left(0,80,160\right.$ and $240 \mathrm{~kg} \mathrm{ha}^{-1}$ of $\left.\mathrm{N}\right)$, made available in the form of urea.

Parcels seeding was carried out mechanically, with six seeds per $\mathrm{m}^{-1}, 4 \mathrm{~cm}$ deep, establishing an initial population of 69000 plants ha $^{-1}$. Experimental parcels dimension was of five-meter long lines, $80 \mathrm{~cm}$ apart, considering the two central lines as usable area and discarding $0.5 \mathrm{~m}$ at each extremity. Usable area of the experimental area was $6.4 \mathrm{~m}^{2}$.

Topdressing nitrogen fertilization was carried out in hauling, when plants showed six totally expanded leaves (V6 stadia of the Ritchie and Hanway scale, 1993), in the form of urea, (45\% of N). Seeds and foliar treatments with Mo used the Ubyfol Potamol ${ }^{\circledR}$ commercial product Formulation is composed of potassium molybdate, showing as chemical guarantees $14 \%$ of $\mathrm{Mo}$ and $12 \%$ of $\mathrm{K}_{2} \mathrm{O}$, with $1.4 \mathrm{~g} \mathrm{~mL}^{-1}$ of density.

Seeds treatment with Mo occurred one day prior to seeding. Treatment included a dosage of the commercial product, corresponding to 20 and $40 \mathrm{~g} \mathrm{ha}^{-1}$ of Mo, for the respective parcels designated to receive Mo, leaving the seeds to dry in the shade after treatment.

Treatment with Mo occurred still in the V6 stadia of the crop, with the help of a pressurized coastal sprayer with $\mathrm{CO}_{2}$. Each block, four parcels received foliar application in the dosage corresponding to $40 \mathrm{~g} \mathrm{ha}^{-1}$ of Mo and, other four parcels received foliar application in the dosage corresponding to $20 \mathrm{~g} \mathrm{ha}^{-1}$ of Mo, complemented by seed treatment.

Plant height and ear insertion evaluation took place during the physiological maturation phase (R6 stadia in the Ritchie and Hanway scale, 1993), with the help of a graded rule (cm). A pachymeter determined stem diameters, by measuring the stem's median diameter of the first internode. Number of ears per plant was determined by collecting ears from all plants in the usable area of each experimental unit and by dividing them by the number of plants in the area. A random collection of ten ears from each usable area of the experimental unit determined the number of grains per ear. Grains were collected from the two central lines, eliminating $0.5 \mathrm{~m}$ at the extremities. Ears were trailed mechanically and production transformed in $\mathrm{kg} \mathrm{ha}^{-1}$ of grains, standardized at $13 \%$ of humidity. Two samples per parcel were removed to determine 100 grains mass, weighed in a precision scale, with eight replications of 100 
grains per experimental unit to obtain a variable mean.

Data were submitted to an analysis of variance with unfolding orthogonal polynomials up to second degree. Mo treatment means were compared by the Tukey test and the $\mathrm{N}$ dosages effects were evaluated through a regression analysis, by adopting as model choice criteria model significance and the determination coefficient $\left(\mathrm{R}^{2}\right)$, at $5 \%$ of probability.

\section{RESULTS AND DISCUSSION}

There was an interaction effect between $\mathrm{N}$ dosages at topdressing and molybdenum application forms for stem diameter, 100 grains mass and grain yield. On the other hand, there was an isolated effect for number of grains per ear for the $\mathrm{N}$ dosages and Mo application forms factors. For plant height and ear insertion characteristics, there was a significant effect only for dosages of topdressing nitrogen fertilization (Table 1).

Table 1. Mean square values for plant height (PH), ear insertion height (EIH), stem diameters (SD), number of grains per ear (NGE), 100 grains mass (M100G) and maze grain yield (GY) analysis of variance in response to molybdenum application forms and topdressing nitrogen fertilization. Londrina, PR, Brazil. 2013.

\begin{tabular}{cccccccc}
\hline & \multicolumn{7}{c}{ Characteristics } \\
\cline { 2 - 7 } Variation source & GL & $\begin{array}{c}\text { PH } \\
(\mathrm{cm})\end{array}$ & $\begin{array}{c}\text { EIH } \\
(\mathrm{cm})\end{array}$ & $\begin{array}{c}\text { SD } \\
(\mathrm{cm})\end{array}$ & NGE & $\begin{array}{c}\text { M100G } \\
(\mathrm{g})\end{array}$ & $\begin{array}{c}\text { GY } \\
\left(\mathrm{kg} \mathrm{ha}^{-1}\right)\end{array}$ \\
\cline { 2 - 7 } Block & 3 & 36.09 & 18.97 & 0.014 & 17659.77 & 1.95 & 1128258.83 \\
Molybdenum (Mo) & 3 & 62.40 & 37.02 & 0.22 & $103120.81^{*}$ & 59.95 & 65795177.42 \\
Nitrogen (N) & 3 & $96.69^{*}$ & $83.69^{*}$ & 0.16 & $49151.35^{*}$ & 26.40 & 47551295.55 \\
Mo*N & 9 & 18.24 & 4.24 & $0.009^{*}$ & 1707.25 & $1.68^{*}$ & $330455.51^{*}$ \\
\hline CV1 (\%) & & 4.28 & 6.15 & 5.20 & 9.74 & 3.60 & 3.65 \\
CV2 (\%) & & 2.25 & 3.64 & 2.53 & 5.25 & 1.31 & 2.40 \\
\hline
\end{tabular}

*Significant at $5 \%$ of probability by the $\mathrm{F}$ test; $\mathrm{CV}$ : variation coefficient.

Plant height and the height of the corn ear insertion adjusted to the increasing linear equation in response to topdressing $\mathrm{N}$ application, with an increase rate of $0.02 \mathrm{~cm}$ at each $\mathrm{kg}$ of macronutrient (Figures $2 \mathrm{a}$ and $2 \mathrm{~b}$ ). Soratto et al. (2010), assessing the effect of $\mathrm{N}$ sources and dosages at topdressing in DKB 979 hybrid maze grown in second crop observed a similar result for plant height; however, for ear insertion height there was no significant effect of the studied factors. Silva et al. (2012), on the other hand, while working with the same cultivar used in the present study, obtained a quadratic adjustment for plant eight adjustment in function of $\mathrm{N}$ dosages, with the highest value for this variable $(110.38 \mathrm{~cm})$ reached by the estimated dosage of $147.9 \mathrm{~kg} \mathrm{ha}^{-1}$ of $\mathrm{N}$ in topdressing.

Plant height and ear insertion height characters increase with the increase in $\mathrm{N}$ dosages in topdressing, since, according to Büll (1993), plants adequately nourished with $\mathrm{N}$ shows greater vegetative development, once the nutrient affects cellular division and expansion and the photosynthetic process directly. However, in the present study it was impossible to detect the response maximum point for these variables, even under the high dosages used, possibly due to the response potential of the cultivar used and the favorable edaphoclimatic conditions.

Table 2 shows that for both treatments with the absence of $\mathrm{N}$ as well as for treatments submitted to the dosage of $160 \mathrm{~kg} \mathrm{ha}^{-1}$ of $\mathrm{N}$ showed similar results in which the application of Mo provided greater stem diameter, regardless of the applied form. As for the $80 \mathrm{~kg} \mathrm{ha}^{-1}$ of $\mathrm{N}$ dosage, treatment $\mathrm{P} 4$ showed the greatest value for this characteristic, and in the dosage of $240 \mathrm{~kg} \mathrm{ha}^{-1}$ of $\mathrm{N}$, the greatest stem diameters were shown by treatments P3 and P4.

Interaction among factors for stem diameter shows that the increase in $\mathrm{N}$ in topdressing for most Mo treatments was positive (Table 2). Mo probably contributed for the increase in plant reserves production, which, according to Magalhães and Jones (1990) are allocated in the height, source of photo-assimilated for several parts of the vegetal.

Figure 2c shows a growing linear adjustment of the stem diameter for most Mo application forms, except for P4. In P4 there is a quadratic adjustment for the variable with maximum response point at $207.8 \mathrm{~kg} \mathrm{ha}{ }^{-1} \mathrm{de} \mathrm{N}$, corresponding to a height diameter of $2.39 \mathrm{~cm}$. The impact of the characteristic in question was smaller without the application of Mo in all dosages of $\mathrm{N}$ in topdressing.

Results for stem diameter corroborate with those obtained by Silva et al. (2012), who, by using the same hybrid $(\mathrm{P} 30 \mathrm{~F} 53 \mathrm{H})$, also verified a quadratic adjustment for this trait, where the highest stem diameter value $(1.74 \mathrm{~cm})$ was for the estimated dosage of $143.97 \mathrm{~kg} \mathrm{ha}^{-1}$ of $\mathrm{N}$ in topdressing. According to Fancelli and Dourado Neto (2005), plants with higher stem diameter can alter grain yield, since the eight acts as a storage structure for soluble solids to be used in the development and filling up of grains. 

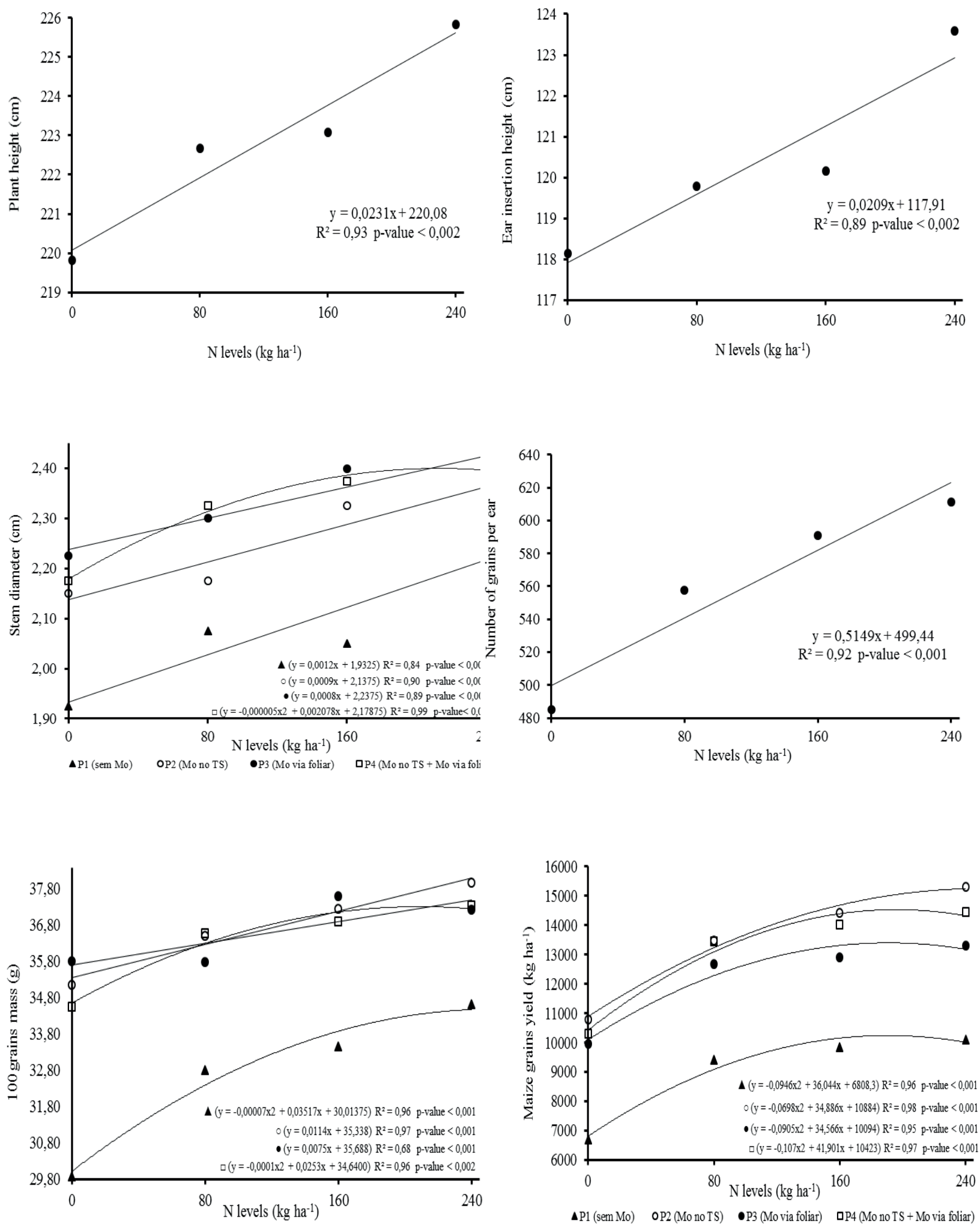

Figure 2. Plant height (a), ear insertion height (b), stem diameter (c), number of grains per ear (d), 100 grains mass (e), and maze grains yield (f) in response to topdressing nitrogen fertilization and mylobdenum application forms. Londrina, PR, Brazil. 2013. 
Table 2. Stem diameter, 100 grains mass and maze grain yield in response to molybdenum application forms and to topdressing nitrogen fertilization. Londrina, PR, Brazil. 2013.

\begin{tabular}{|c|c|c|c|c|}
\hline \multirow{3}{*}{ Molybdenum } & \multicolumn{4}{|c|}{ Stem diameter $(\mathrm{cm})$} \\
\hline & \multicolumn{4}{|c|}{$\mathrm{N}$ dosage $\left(\mathrm{kg} \mathrm{ha}^{-1}\right)$} \\
\hline & 0 & 80 & 160 & 240 \\
\hline P1 (without Mo) & $1.93 \mathrm{~B}^{1}$ & $2.08 \mathrm{C}$ & $2.05 \mathrm{~B}$ & $2.25 \mathrm{~B}$ \\
\hline P2 (Mo nin ST) & $2.15 \mathrm{~A}$ & $2.18 \mathrm{BC}$ & $2.33 \mathrm{~A}$ & $2.35 \mathrm{AB}$ \\
\hline P3 (Mo via foliar) & $2.23 \mathrm{~A}$ & $2.30 \mathrm{AB}$ & $2.40 \mathrm{~A}$ & $2.40 \mathrm{~A}$ \\
\hline P4 (Mo in ST + via foliar) & $2.18 \mathrm{~A}$ & $2.33 \mathrm{~A}$ & $2.38 \mathrm{~A}$ & $2.40 \mathrm{~A}$ \\
\hline CV1 (\%) & \multicolumn{4}{|c|}{5,20} \\
\hline \multirow[t]{4}{*}{ CV2 (\%) } & \multicolumn{4}{|c|}{2,53} \\
\hline & \multicolumn{4}{|c|}{100 grains mass $(\mathrm{g})$} \\
\hline & \multicolumn{4}{|c|}{$\mathrm{N}$ dosage $\left(\mathrm{kg} \mathrm{ha} \mathrm{a}^{-1}\right)$} \\
\hline & 0 & 80 & 160 & 240 \\
\hline P1 (without Mo) & $29.88 \mathrm{~B}$ & $32.80 \mathrm{~B}$ & $33.45 \mathrm{~B}$ & $34.60 \mathrm{~B}$ \\
\hline P2 (Mo in ST) & $35.15 \mathrm{~A}$ & $36.50 \mathrm{~A}$ & $37.23 \mathrm{~A}$ & $37.95 \mathrm{~A}$ \\
\hline P3 (Mo via foliar) & $35.80 \mathrm{~A}$ & $35.78 \mathrm{~A}$ & $37.58 \mathrm{~A}$ & $37.20 \mathrm{~A}$ \\
\hline P4 (Mo in ST + via foliar) & $34.55 \mathrm{~A}$ & $36.55 \mathrm{~A}$ & $36.88 \mathrm{~A}$ & $37.33 \mathrm{~A}$ \\
\hline CV1 (\%) & \multirow{2}{*}{\multicolumn{4}{|c|}{$\begin{array}{l}3.60 \\
1.31 \\
\end{array}$}} \\
\hline \multirow[t]{4}{*}{ CV2 (\%) } & & & & \\
\hline & \multicolumn{4}{|c|}{ Grain yield $\left(\mathrm{kg} \mathrm{ha}^{-1}\right)$} \\
\hline & \multicolumn{4}{|c|}{$\mathrm{N}$ dosage $\left(\mathrm{kg} \mathrm{ha}^{-1}\right)$} \\
\hline & 0 & 80 & 160 & 240 \\
\hline P1 (without Mo) & $6701.96 \mathrm{C}$ & $9405.04 \mathrm{C}$ & $9833.72 \mathrm{C}$ & 10114.21 D \\
\hline P2 (Mo in ST) & 10801.36 A & $13476.25 \mathrm{~A}$ & 14431.22 A & $15319.62 \mathrm{~A}$ \\
\hline P3 (Mo via foliar) & $9961.21 \mathrm{~B}$ & $12677.75 \mathrm{~B}$ & 12909.73 B & $13309.50 \mathrm{C}$ \\
\hline P4 (Mo in ST + via foliar) & $10302.16 \mathrm{AB}$ & $13453.51 \mathrm{~A}$ & $14025.36 \mathrm{~A}$ & $14437.78 \mathrm{~B}$ \\
\hline CV1 (\%) & & & & \\
\hline CV2 (\%) & & & & \\
\hline
\end{tabular}

${ }^{1}$ Means followed by the same letter in the columns show no statistical difference among them by the Tukey test at 5\% of probability. N: nitrogen; Mo: molybdenum; ST: Seeds treatment; CV: Variation coefficient.

The application of Mo led to greater number of grains per ear, regardless of the application form (Table 3). According to Taiz and Zeiger (2009), by participating in the assimilation of $\mathrm{N}$ by plants, Mo may contribute to greater supply to this element to plants during the processes involved in grains formation, which may have favored the increase in number of grains per ear by the application of this micronutrient.

Table 3. Number of grains per ear in response to molybdenum application forms. Londrina, PR, Brazil. 2013.

\begin{tabular}{lc}
\hline \multirow{2}{*}{ Molybdenum } & Number of grains per ear \\
\cline { 2 - 2 } P1 (without Mo) & Means \\
P2 (Mo in ST) & $441.44 \mathrm{~B}^{1}$ \\
P3 (Mo via foliar) & $606.56 \mathrm{~A}$ \\
P4 (Mo in ST + via foliar) & $589.63 \mathrm{~A}$ \\
\hline CV1 (\%) & $607.31 \mathrm{~A}$ \\
\hline CV2 (\%) & 9.74 \\
\hline Means followed by the same letter in the columns show no statistical difference among them by the Tukey test at 5\% of probability N: nitrogen; Mo:
\end{tabular}

${ }^{1}$ Means followed by the same letter in the columns show no statistical difference among them by the Tukey test at 5\% of probability. N: nitrogen; Mo: molybdenum; ST: Seeds treatment; CV: variation coefficient.

For Ernani et al. (2005), the insufficient supply of $\mathrm{N}$ during the floral differentiation stadia may reduce the number of eggs in the early stages of ear development thus reducing grain yield.

In response to $\mathrm{N}$ applied in topdressing, the number of grains per ear increased linearly ( 0.5 grains for each $\mathrm{kg}$ of $\mathrm{N}$ added) (Figure 2d). These results corroborate with those found by Torres et al. (2014) in which $\mathrm{N}$ fertilization in topdressing also increased the number of grains per year linearly. According to Marschner (1995), high dosages of $\mathrm{N}$ led to an increase in gibbelleric acid content, causing proteic synthesis and greater flourishing and, as a result, there is an increase in number of flowers per ear, which explains the increase in number of grains per ear. 
Treatments with Mo, regardless of the application form, promoted an increase in 100 grains mass in all dosages of $\mathrm{N}$ applied in topdressing, as well as in the absence of $\mathrm{N}$ in topdressing (Table 2). This increase was possibly due to nutrients that favored plant growth with the increase in photosynthesis and consequently greater synthesis of photoassimilated, which favored greater grain development (Below 2002).

For 100 grains mass, treatments $\mathrm{P} 2$ and $\mathrm{P} 3$ adjusted to the increasing linear functions, in response to the increase in topdressing nitrogen fertilization. As for P1 and P2, on the other hand, the adjustment was quadratic with values estimated in $254.87 \mathrm{~kg} \mathrm{ha}^{-1}$ of N and $207.74 \mathrm{~kg} \mathrm{ha}^{-1}$ of N, respectively (Figure 2e). This also occurred in the study conducted by Ferreira et al. (2001), where tis characteristic also adjusted itself to the quadratic model as the $\mathrm{N}$ dosages increased.

The increase in 100 grains mass in function of the increase in topdressing nitrogen fertilization may have occurred once the high dosages of the $\mathrm{N}$ maintained the photosynthetic activity for a longer period, resulting in a greater accumulation of reserves in the grains (Dourado Neto et al., 2004; Silva et al. (2006a) revealed that this yield component can alter the final production of the crop, since it is possible to obtain greater yield from a certain number of eggs only by increasing the reserves accumulated in the grains.

As for grain yield, the absence of $\mathrm{N}$ in topdressing showed greater yield, although not different from $\mathrm{P} 4$ (Table 2). However, the molybdic fertilization in topdressing increased yield even in the absence of N. Higher yields were also observed in intermediate dosages of $\mathrm{N}$ in topdressing, with the same Mo application forms. On the other hand, for higher dosages of N, greater yield was obtained by P2. Silva et al. (2011) also reported on maze yield increases under different dosages of molybdic fertilization.

There was a grain yield quadratic adjustment in relation to $\mathrm{N}$ dosages in the absence of Mo as well as in all application forms (Figure 2f). Treatments P1, P2, P3 and P4 reached the maximum efficiency point in doses estimated of 190.44, 249.95, 190.97 and $195.82 \mathrm{~kg} \mathrm{ha}^{-1}$ of $\mathrm{N}$, respectively. However, data are not in agreement with Ferreira et al. (2001), who found that grain yield was influenced only by increases in $\mathrm{N}$ dosages, without an interaction with Mo.

Silva et al. (2011) verified increases in maze yield in response to different dosages of molybidic fertilization, with variations between cultivation years, probably due to rainfall variation and other weather elements such as temperature and luminosity.

Treatments $\mathrm{P} 2$ and $\mathrm{P} 4$ showed better results for maze grain yield when compared to treatments $\mathrm{P} 1$ and $\mathrm{P} 3$. Table 2 shows that all Mo application forms provided better values for the trait in relation to the absence of the application.

$\mathrm{N}$ dosages applied in topdressing, as well as the application of Mo, increase maze grain yield. The absence of $\mathrm{N}$ in topdressing had an effect on grain yield, indicating that the presence of the micronutrient also potentiating the effect of nitrogen fertilization in the base. This could be the result of a more efficient nitrate assimilation reduction, for the incorporation of $\mathrm{N}-\mathrm{NH}_{3}$ in organic compounds promoted by Mo supplementation.

According to Li-Ping, Yang-Rui and Li-Tao (2007), whenever the supply of Mo is unsatisfactory, the nitrate reductase enzyme activity is reduced and, consequently, the assimilation of $\mathrm{N}$ is also reduced. However, when provided adequately, there is an increase in both enzyme activity and $\mathrm{N}$ contents. Thus, due to its regulator role, the nitrate reductase may be related to crop yield. Maze crops grain yield depends directly on the plant's photosynthetic activity in which the photosynthesis, in turn, depends on the foliar area and the leaves permanence time during the plant's activity (Fancelli and Dourado Neto, 2008). According to Basi et al. (2011) N is determinant for the plants growth, development and yield since it can influence physiological processes considered essential for vegetal life maintenance.

Results show that the application of $\mathrm{N}$ can be optimized in the presence of Mo, offering more efficient $\mathrm{N}$ nourished maze plants. This can be an alternative for a more rational, efficient and sustainable use of nitrogen fertilizers, contributing to the increase in grain yield and helping growers to reach modern maze cultivars production levels.

\section{CONCLUSIONS}

The increase in $\mathrm{N}$ dosages in topdressing increases plant height, ear insertion height, stem diameter, number of grains per ear, 100 grains mass and grain yield in maze crops.

The application of molybdenum improves $\mathrm{N}$ use by maze crops.

The application of molybdenum via maze seeds treatment, in partial or total dosages, brings better results compared to foliar applications.

\section{REFERENCES}

Basi S, Neumann M, Marafon F, Ueno RK and Sandini IE (2011) Influência da adubação nitrogenada sobre a qualidade da silagem de milho. Revista Brasileira de Tecnologia Aplicada nas Ciências Agrárias (4): 219-234. 
Below FE (2002) Fisiologia, nutrição e adubação nitrogenada do milho. Potafos, Piracicaba.

Büll LT (1993) Nutrição do milho. In: Büll LT, Cantarella H (eds). Cultura do milho: fatores que afetam a produtividade. Potafos, Piracicaba, pp. 71-104.

Cantarella H and Duarte AP (2004) Manejo da fertilidade do solo para a cultura do milho. Galvão JCC, Miranda GV (Eds.) Tecnologia de produção de milho. Universidade Federal de Viçosa, Viçosa, pp. 139-182.

Dourado Neto D, Favarin JL, Manfron PA, Pilau FA, Soares MA, Bonnecarrere RAG and Ohse S (2004) Efeito de boro e nitrogênio na cultura do milho. Insula (1): 51-67.

Empresa Brasileira de Pesquisa Agropecuária (2006) Centro Nacional de Pesquisa de Solos. Sistema brasileiro de classificação de solos. 7.ed. Embrapa, Rio de Janeiro, 306p.

Ernani PR (2003) Disponibilidade de nitrogênio e adubação nitrogenada para a macieira. Graphel, Lages, 76p.

Ernani PR, Sangoi L, Lech VA and Rampazzo C (2005) A forma de aplicação da ureia e dos resíduos vegetais afeta a disponibilidade de nitrogênio. Ciência Rural 35(2): 360-365.

Fancelli AL (2010) Boas práticas para uso eficiente de fertilizantes. IPNI Brasil, Piracicaba, 16p.

Fancelli AL and Dourado Neto D (2008) Produção de milho. 2.ed. Agropecuária, Guaíba, 360p.

Fancelli AL and Dourado Neto D (2005) Milho: tecnologia e produção. ESALQ/USP/LVP, Piracicaba, p. 118-128.

Ferreira ACB, Araújo GAA, Pereira PRG and Cardoso AA (2001) Características agronômicas e nutricionais do milho adubado com nitrogênio, molibdênio e zinco. Scientia Agricola (58): 131-138.

Ferreira MGP, Brito MEB, Costa FB, Araújo Filho GD and Alvino FCG (2011) Aspectos químicos e físicos dos grãos do milho doce sob estresse hídrico. Revista Brasileira de Agrotecnologia 1(1): 1-6.

Li-Ping W, Yang-Rui L and Li-Tao Y (2007) Effects of Molybdenum on Nitrogen Metabolism of Sugarcane. Shugar Technology 9(1): 36-42.

Magalhães PC and Jones R (1990) Aumento de fotoassimilados na taxa de crescimento e peso final dos grãos de milho. Pesquisa Agropecuária Brasileira 25(12): 1747-1754.

Marschner H (1995) Mineral nutrition of higher plants. Academic Press Limited, London, 889p.

Martens DC and Westermann DT (1991) Fertilizers application for correcting micronutrients deficiencies. Mortvedt JJ, Cox FR, Shuman LM and Welch RM (eds) Fertilizers applications for correcting micronutriente deficiencies: micronutrients in agriculture. 2. ed. Soil Science Society of America, Madison, pp. 549-592.

Ohland RAA, Souza LCF, Hernani LC, Marchetti ME and Gonçalves MC (2005) Culturas de cobertura do solo e adubação nitrogenada no milho em plantio direto. Ciência e Agrotecnologia 29(3): 538-544.

Raij BV (2011) Fertilidade do solo e manejo de nutrientes. International Plant Nutrition Institute, Piracicaba, 420p.

Silva AA, Silva TS, Vasconcelos ACP and Lana RMQ(2012) Aplicação de diferentes fontes de ureia de liberação gradual na cultura do milho. Bioscience Journal (28): 104-111.

Silva SM, Oliveira LJ, Faria FP, Reis EF, Carneiro MAC and Silva SM (2011) Atividade da enzima nitrato redutase em milho cultivado sob diferentes níveis de adubação nitrogenada e potássica. Ciência Rural 41(11): 1931-1937.

Silva AD, Vitorino ACT, Souza LCF, Gonçalves MC and Roscoe R (2006a) Culturas antecessoras e adubação nitrogenada na cultura do milho, em sistema de plantio direto. Revista Brasileira de Milho e Sorgo (5): 75-88. 
Silva EC, Muraoka T, Buzetti S and Trivelin PCO (2006b) Manejo de nitrogênio no milho sob plantio direto com diferentes plantas de cobertura, em Latossolo Vermellho. Pesquisa Agropecuária Brasileira 41(3): 477-486.

Soratto RP, Pereira M, Costa MTA and Lampert VN (2010) Fontes alternativas e doses de nitrogênio no milho safrinha em sucessão à soja. Revista Ciência Agronômica 41(4): 511-518.

Taiz L and Zeiger E (2009) Fisiologia vegetal. 4.ed. Artmed, Porto Alegre, 819p.

Torres FE, Souza LCF, Andrade LHL, Pedroso FF, Matoso AO, Torres LD, Benett CGS and Benett KSS (2014) Influência da cobertura do solo e doses de nitrogênio na cultura do milho safrinha. Revista Brasileira de Ciências Agrárias 9(1): 36-41.

Yano GT, Takahashi HW, Watanabe TS (2005) Avaliação de fontes de nitrogênio e épocas de aplicação em cobertura para o cultivo do trigo. Semina: Ciências Agrárias 26(2): 141-148.

Received: August 31, 2017.

Accepted: October 19, 2017.

Published: December 15, 2017. 